Review

\title{
Gulf of Mexico Seafood Harvesters, Part 2: Occupational Health-Related Risk Factors
}

\author{
Melvin L. Myers 1,2,*, Robert M. Durborow ${ }^{2,3}$ and Andrew S. Kane 2,4 \\ 1 Rollins School of Public Health, Emory University, Atlanta, GA 30322, USA \\ 2 Southeastern Coastal Center for Agricultural Health and Safety, University of Florida, \\ Gainesville, FL 32611, USA; Robert.durborow@kysu.edu (R.M.D.); kane@ufl.edu (A.S.K.) \\ 3 Land Grant Program and State Extension Specialist for Aquaculture, Kentucky State University, \\ Frankfort, KY 40601, USA \\ 4 Department of Environmental and Global Health, College of Public Health and Health Professions, \\ University of Florida, Gainesville, FL 32611, USA \\ * Correspondence: melvinmyers@charter.net; Tel.: +1-404-310-5061
}

Received: 18 April 2018; Accepted: 12 June 2018; Published: 25 June 2018

\begin{abstract}
The purpose of this literature review, the second in a series following one on traumatic injuries and fatigue, is to identify potential health hazards to inform a study of occupational health and safety among fish harvesters in the Gulf of Mexico (GoM). Fish harvesters are potentially at a high risk of occupational illnesses in GoM fisheries. GoM fishers engage in harvesting shrimp, finfish, oysters, crabs, and clams. Method: The method is a narrative literature review. Search terms that included safety, seafood, occupational, fishing, oyster, clam, shrimp, crab, and GoM were used to identify relevant literature in combination (i.e., a string search). Results: A total of 53 manuscripts were reviewed, of which only two regarded the GoM, but 19 were from the US Atlantic Coast. Musculoskeletal disorders are widespread across the fishing sector. Other hazards include bites and stings from aquatic animals (some of which may be life-threatening), vessel engine noise, dermatoses, and other skin afflictions (including possible strep infection of wounds), solar ray-induced eye diseases, and respiratory exposures (such as to protein aerosols) that can cause asthma. Diving poses multiple breathing and other hazards. Conclusion: While fish harvesters are protected from respiratory problems when working on the well-ventilated deck and dermal hazards by wearing gloves, musculoskeletal, bite and sting, ocular, engine-related hearing loss, and skin, lip, and eye cancer hazards are potentially serious risks among GoM fish harvesters.
\end{abstract}

Keywords: fishing; hazards; health effects; musculoskeletal; ocular; respiratory; dermal; noise; animal stings; occupational

\section{Introduction}

"Scant research has addressed the health and occupational health risks among Gulf of Mexico fishermen."-Ann K. Carruth et al., 2010 [1]

While much research has addressed the problem of injuries among fishers, comparatively little has addressed their other adverse health effects. The following narrative describes one incident in which fish harvesters fell ill because of an exposure after a fishing haul.

In 1991, four men participated in the last halibut derby in Alaska on a party boat to earn credits for an anticipated switch to a fishing quota system. They caught their haul within the short 24-h season but overloaded their boat. On the trip back to port, the diesel engine struggled with the heavy load. While one man was at the helm on top, the others sought shelter inside a cabin that opened to the rear. The helmsman checked on the deck crew below. All were unconscious, and he was overtaken by carbon 
monoxide fumes that rose over the rear gunwale from the engine and into the cabin (a phenomenon known as the station wagon effect). He made a mayday call. The US Coast Guard (USCG) responded and found all four men unconscious but alive. The USCG transported them to the hospital and towed the boat back to dock. The four survived. (Source: personal observations by the first author).

This literature review aims to identify and describe potential occupational health risk factors to inform a study of health and safety among fishers in the Gulf of Mexico (GoM). This review is the second in a series, in which the first addressed fatigue and fatal and nonfatal injury risk factors among fishers [2], and the third review describes several known countermeasures to prevent injuries, disorders, and illnesses among fish harvesters with a focus on the GoM [3].

Previous reviews regarding health problems among fish harvesters were consulted. In 1998, the International Labor Office (ILO) reviewed health problems and disease patterns among fishers that included injuries, hearing loss, poisoning and asphyxiation, skin diseases and cancer. Lip cancer was related to smoking and solar radiation. Lung cancer was attributed to smoking, and stomach cancer to diet [4]. An additional ILO study addressed musculoskeletal disorders [5]. One review focused on lifestyle risk factors among fishers-tobacco, alcohol, diet, physical activity, overweight, and fatigue [6]. Another review divided acute mortality into fatalities $(21.8 \%)$, disease $(18.7 \%)$, and homicide and suicide (3.1\%) from a United Kingdom (UK) study. It also reported on a small study in which dock workers and fishers died of cardiovascular diseases. Non-UK mortality studies found significant deaths from" internal" heart conditions and fatalities. In another study, which was reviewed, poisoning in holds from carbon dioxide and hydrogen sulfide was identified, but in other studies lung and liver cancers were associated with smoking. Overall, studies of morbidity related to injuries, but other health problems included alcohol inebriation and several health conditions that may not be occupational such as dental, digestive, mental, cardiovascular, and urogenital conditions [7]. Nonetheless, many of these conditions may affect fitness for work. Work-related conditions included solar keratosis, musculoskeletal disorders, chronic bronchitis, and wound infections. The healthy worker effect was noted and occurs when healthy workers remain in a cohort, and those who become ill or disabled and leave the cohort, thus they are excluded in a study.

When ILO addressed aquaculture, mariculture was part of the review. Risk factors involved the construction and maintenance of complex structures under harsh environmental conditions. Health problems included repetitive strain, sleep deprivation, decompression illness among divers, organophosphate poisoning when treating sea lice, toxic algaecides, formaldehyde exposure, toxic agents, respiratory illness from a variety of exposures to feed, sunburn and keratotomy skin injury from ultraviolet sun exposure, and a variety of skin diseases from constant wet conditions [8].

\subsection{The Problem}

Commercial fishers work in one of the most dangerous jobs in the world [9], and Florida has the third highest fatality rate for fish harvesters after Alaska and Massachusetts [10]. Other adverse health outcomes among GoM fishers relate to musculoskeletal, aquatic animal, skin, eye, breathing, and hearing hazards.

Fish harvesting involves a variety of vessels, gear, and techniques. Chauvin et al. classified fishing operations into active and passive techniques [11]. Examples of active techniques include purse seine, trawl, and dredge technologies in which the vessel's mobility is used to harvest the catch (Figure 1). Passive techniques rely on capturing fish by stationary means and typically include stopping the vessel to harvest the fish or shellfish (Figure 2). Examples of passive harvest techniques are retrieving the shellfish from grow-out bags (in mariculture), finfish from gillnets, oysters with tongs, and crabs from pots (traps). 


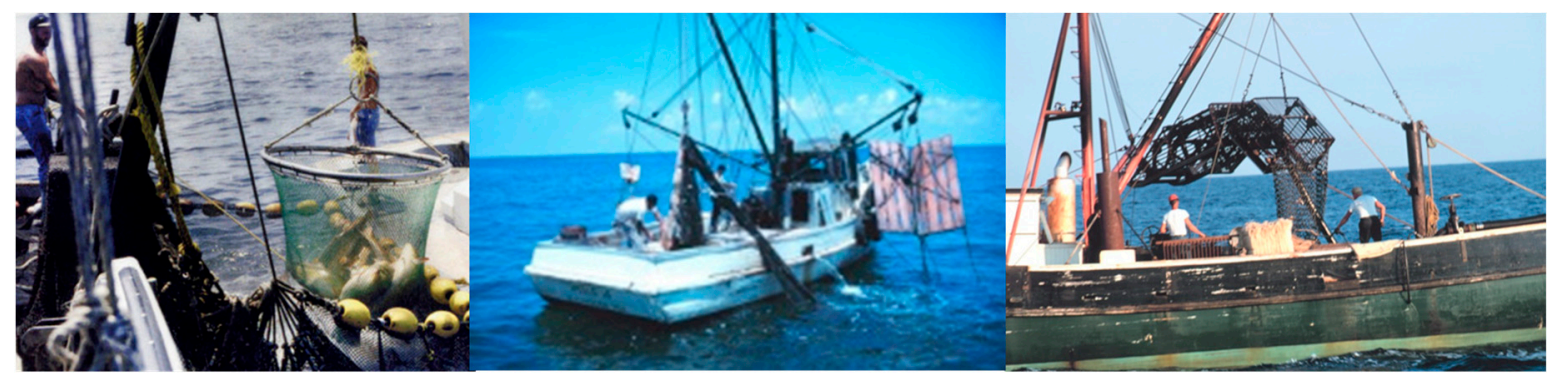

Purse seine finfish haul Shrimp otter trawl vessel

Oyster/clam dredge

Figure 1. Active fishing work in the Gulf of Mexico or Atlantic seaboard in which vessel motion under power is used to net the catch. Courtesy of the US National Oceanic and Atmospheric Administration photograph library.

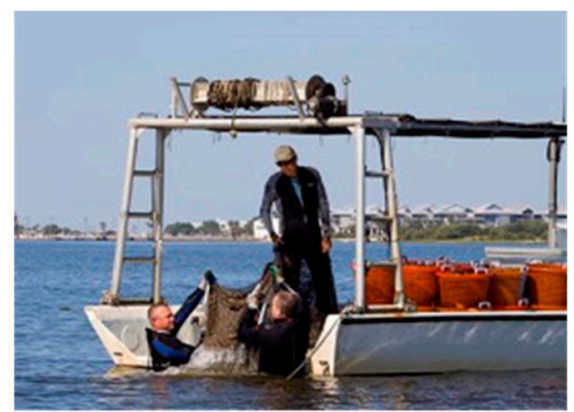

Clam mariculture harvest

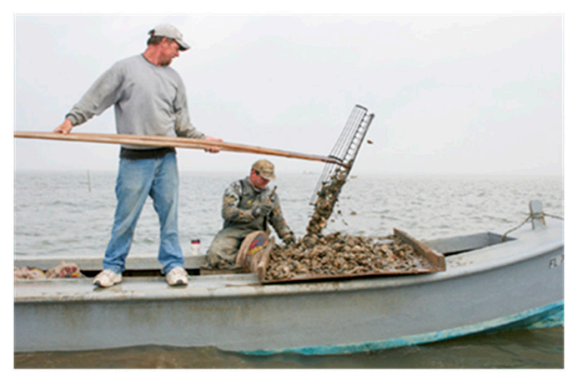

Oyster harvest with tongs

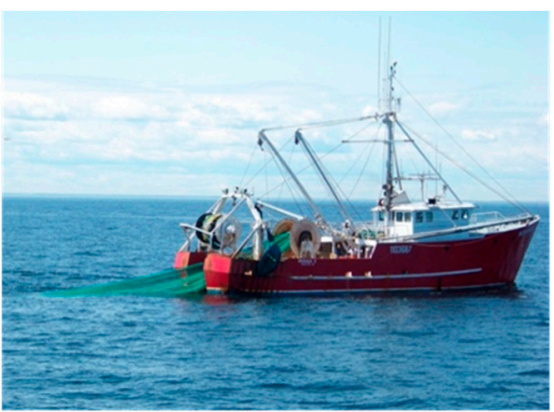

Finfish gillnet fishing

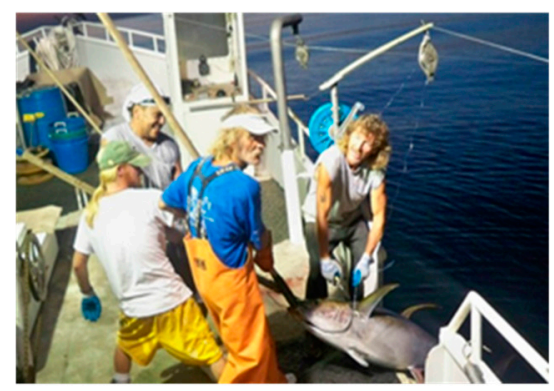

Finfish line fishing

Figure 2. Passive fishing work in the Gulf of Mexico in which fish are harvested while the vessel is stationary. Sources: Clam harvest and Oyster harvest-Courtesy of University of Florida Institute of Food and Agricultural Services; Gillnet fishing and Line fishing-Courtesy of the US National Oceanic and Atmospheric Administration photograph library.

\subsection{Purpose}

Informed by this review, a study of occupational health and safety of GoM seafood workers addresses the safety and health of fish harvesters in five fisheries: shrimp, crab, finfish, oyster, and clam. The purpose of this review is to determine risk factors (i.e., hazards) that contribute to occupational disorders and diseases, which exist or may exist among GoM fish harvesters and mariculturalists.

\section{Method and Materials}

This study expands on the above former reviews with a focus on specific occupational disease and disability categories. The method is a narrative literature review and is the same as used in a previous review that addressed traumatic injuries. The current review focuses on work-related risk factors that 
affect the health of fish harvesters. Databases consulted included PubMed (http:/ / www.ncbi.nlm.nih. gov / pubmed), National Institute for Occupational Safety and Health (NIOSH; http:/ / www.cdc.gov / niosh/topics/fishing/default.html), the USCG (http:/ /www.fishsafe.info/), Google Scholar (https: //scholar.google.com/), Research Gate (https://www.researchgate.net/home), and authors' files. Search terms include occupational safety and health and fishery-related words that included safety, work, seafood, NOAA, occupational, health, fishing, oyster, clam, shrimp, crab, and GoM. A follow-on string search was made of the terms fishing or fishermen against known occupational health effects or exposures that included musculoskeletal, aquatic animal stings, dermal, ocular, respiratory, hearing, and noise. While studies since 2004 were a primary focus, some studies, particularly regarding ocular hazards, moved the search to earlier cited literature. A unique term, "watermen" used in Maryland for fish harvesters, was critical for the discovery of several important sources. Selection criteria were based upon three priorities: (1) direct or indirect relevance to GoM fisher safety and health, (2) recent investigations that build on earlier investigations, and (3) research designs that can inform our study. The review analyzed 52 articles, which are listed in the Appendix A: Literature Reviewed by the geographic origin of the referenced study, topic, and health problem addressed.

\section{Results}

The review examined the literature to discern the severity and extent of occupational disabilities and diseases among fishers. Our review results are classified as: musculoskeletal, aquatic animal, skin, ocular, breathing, hearing, and mariculture hazards.

\subsection{Musculoskeletal Hazards}

Studies of musculoskeletal hazards dominate the literature regarding occupational health effects among fishers. Kaerlev et al. found that Danish fishers and seafarers exceeded the national rates for diseases of the nervous system; gastrointestinal system; bones, muscles, and soft tissues; and lesions to one or more body regions, as well as skin diseases [12]. Musculoskeletal disorders can result from acute or chronic stress or strain. Mirka et al. reviewed the musculoskeletal challenges experienced by North Carolina crabbers in 2011 and described the working conditions of the fishers: long hours of work; a dynamic work environment that included excessive heat, frigid cold, high winds, and a variety of precipitation; and a wet and moving work surface while standing, which creates three-dimensional inertial forces [13]. Musculoskeletal risk factors experienced by crabbers included repetitive bending and lifting, awkward postures, high force lifting exertions, upper extremity repetitive motion and exertions, slip and fall exposure, extreme muscle fatigue, and static tasks (e.g., boat driving, net reel running, gear setting, catch sorting (shown in Figure 3), and boat and gear cleaning and maintenance. They reviewed the epidemiologic literature regarding fishing and made the following observations:

- Törner et al. (1988) - 74\% of Swedish fishers reported musculoskeletal symptoms over the previous 12 months; more than half experienced low back symptoms [14].

- Norrish and Cryer (1990)—lifting, lowering, loading, and unloading boxes by New Zealand deep sea fishers represented $39 \%$ of compensated cases of which back strains accounted for two-thirds of the strain and sprain type injuries and $36 \%$ of compensation cost [15].

- Jensen (1996)—sprains and strains represented 10\% of injuries among Danish fishers, $10 \%$ of which were back injuries [16].

- Chauvin and Le Bouar (2007) and Antäo et al. (2008)—back injuries are important outcomes of injury incidents $[17,18]$.

- Kucera et al. (2008) — detailed the time that crabbers spend on tasks by the captain and each of two deck hands in a study of low back stress [19]. 


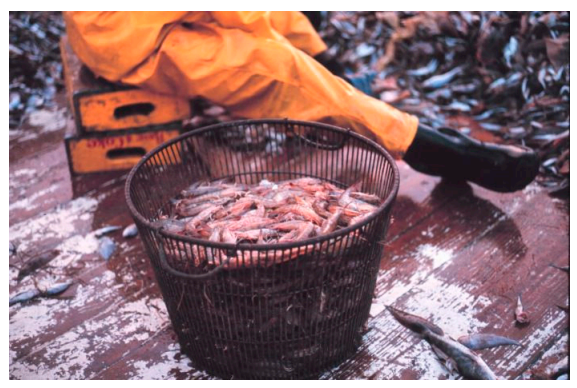

Figure 3. An example of static work: sorting and placing shrimp into baskets. Courtesy of the US National Oceanic and Atmospheric Administration photograph library.

Kucera et al. conducted another study in 2009 in North Carolina that identified high-hazard tasks for low back pain in the crab pot and gillnet fishing sectors, which included $\leq 15 \%$ spine comparisons among those who handled heavy loads [20]. The study found that younger workers experienced more back pain than older workers, which was attributed to a possible healthy worker effect. More than $90 \%$ of 89 subjects reported musculoskeletal risks of loading bait and/or supplies and pulling in, emptying, securing, and setting gear. They also reported that half of their time involved cleaning the boat. Of the respondents, most fished alone at $70 \%$ of crab pot and $64 \%$ of gillnet fishing jobs. Self-reported high-risk tasks included running the puller or net reel, sorting catch onboard, and unloading the catch or supplies. Low-risk tasks were driving the boat; loading bait and supplies; pulling, emptying, or setting gear; cleaning the boat; and maintenance work. The investigators identified static tasks with awkward postures for sorting, manual loading and unloading, and operating pullers and net reels as modifiable risk factors.

In a 2010 article, Kucera and Lipscomb used the Posterior, Activity, Tools, and Handling (PATH) method (see Table 1) to identify hazardous tasks and activities to the musculoskeletal system among a sample of $25 \mathrm{crab}$ fishers in 11 crews in North Carolina [21]. Swedish researchers accompanied the crews during work and recorded observations every $90 \mathrm{~s}$. High-stress activities were hooking the buoy, feeding the pot puller, and handling/operating the crab pot, all of which involved multiple risk factors. Crews hauled between 200 and 600 pots per day, of which each weighed between 10 and 30 pounds ( 4.5 and $13.6 \mathrm{~kg}$ ) per pot depending on the amount of catch. Fishers said pulling the pot in by hand was 2.5 times more stressful than using a pot puller. While reducing the stress on the captain, adding a crew member did not necessarily reduce the stress on the first mate since the additional crew member would likely sort the catch on the deck rather than assist with retrieving the pots. Rest cycles lasted between 10 and $40 \mathrm{~s}$ during travel between buoys. Stress was greater with a higher distance between the deck and the water surfaces. The authors found that awkward shoulder postures varied by technique, task distribution, equipment, and type of boat and setup [22].

Table 1. Posterior, Activity, Tools, and Handling (PATH) Categories in a Shoulder Risk Factor Study, North Carolina, $n=25$ crab fishers.

\begin{tabular}{|c|c|c|c|c|}
\hline Phase (task) & Posterior & Activity & Tools & Handling \\
\hline $\begin{array}{l}\text { - Pre-fishing } \\
\text { - Loading } \\
\text {-Dock/cast off } \\
\text { - Traveling } \\
\text {-Pulling pots } \\
\text { - Setting pots } \\
\text {-Unloading } \\
\text { - Clean } \\
\text { - Sort/cull/pack } \\
\text { catch } \\
\text {-Post-fishing } \\
\text { - Other }\end{array}$ & $\begin{array}{l}\text {-Extension of arm above shoulder and abduction } \\
\text { - Both arms raised v. one arm raised } \\
\text { - Frequency of 2-handed and 1-handed tool use } \\
\text { - Orientation to task } \\
\text { - Repetition } \\
\text { - Static work } \\
\text { - Hand-held weight or force } \\
\text { - Rest }\end{array}$ & $\begin{array}{l}\text {-Operate controls } \\
\text {-Handle hook } \\
\text {-Hook the buoy } \\
\text {-Feed rope into puller } \\
\text { - Handle/guide rope } \\
\text { - Handle/operate pot } \\
\text {-Bait pot } \\
\text {-Set pot } \\
\text { - Handle/sort catch } \\
\text {-Idle } \\
\text { - Other }\end{array}$ & $\begin{array}{l}\text { - Hook } \\
- \text { Crab pot } \\
\text { - Box/crate } \\
\text { - Basket } \\
\text { - Tote } \\
\text { - Hose } \\
\text { - Other }\end{array}$ & $\begin{array}{l}\text { - Lift } \\
\text {-Push/pull } \\
\text { - Lower } \\
\text {-Slide } \\
\text {-Carry } \\
\text { - Other }\end{array}$ \\
\hline
\end{tabular}

Source: Kucera and Lipscomb, 2010 [21]. 
In another study, of musculoskeletal symptoms, Lipscomb et al. collected information in North Carolina from 215 volunteer fishers over a 12-month period and from field visits to observe workplace exposures [23]. The fishing locations included inland sounds, coastal rivers, and offshore operations. Small crews or single fishers typically engaged in inland fishing of finfish, crabs, shrimp, oysters, and clams. The top five body locations of musculoskeletal symptoms by incidence were low back $(n=52,24 \%)$, hand and wrists $(n=41,19 \%)$, knees $(n=29,13 \%)$, elbows and forearms $(n=27,12 \%)$, and shoulders $(n=25,12 \%)$.

In 2002, Fulmer and Buchholz conducted a case study of Massachusetts fishers of risk factors associated with work processes that could be reduced by applying ergonomic principles [24]. They investigated two lobster boats, a gillnetter that used stationary gear, and a trawler that used mobile gear. The musculoskeletal risk factors included frequent hauling of traps, lifting full and heavy buckets, and handling bait and catch, all of which were repetitive and required speed and precision. The haul of the catch also contained debris, some of which was very heavy that needed to be removed from the nets. To prevent tangling, fishers used a lot of static force to guide the line with a bar during the haul. They dropped the catch onto the deck for sorting and putting into baskets, which required bending and kneeling. The deckhands carried the full 80-pound baskets into the hold.

Fulmer et al. conducted another study of musculoskeletal pain among 395 lobstermen from 276 vessels in Maine and Massachusetts for the period 2012-2014 [25]. Of the respondents, 248 (62\%) reported pains caused by work, $103(26 \%)$ received treatment for the pain, and $50(12 \%)$ had to alter work or stop working. Body parts affected included the lower back $(36 \%)$; the knee, shin, or calf $(17 \%)$; the right shoulder (14\%); both hands and wrists $(11 \%)$; and both shoulders $(11 \%)$.

Kaerlev et al. conducted a study of musculoskeletal disorders among Danish fishers for two five-year periods starting employment in the years $1994(n=4570)$ and $1999(n=3470)$ [26]. They calculated standardized incident ratios (SIR) in which 100 is normal. They identified 546 $(\mathrm{SIR}=122, \mathrm{CI}=113-133)$ and $494(\mathrm{SIR}=118, \mathrm{CI}=108-129)$ cases of musculoskeletal disorders among the 1994-1998 and 1999-2003 cohorts, respectively. The highest SIR for fishers was for thoracic-lumber disc disorders (224, CI $=189-266$ and $178, C I=141-222$, respectively), rotator cuff syndrome (225, $C I=138-266$ and $205 \mathrm{CI}=127-313$, respectively), and carpal tunnel syndrome (315, CI $=233-418$ and $292, \mathrm{CI}=214-389$, respectively). These data excluded cases treated outside of the hospital and untreated cases.

\subsection{Aquatic Animal Hazards}

"In the maritime environment, characterized by a great biodiversity, employees can be, during their work, exposed to chemical and above all biological substances."-David Lucas, et al., 2006 [27]

Exposure to dangers such as bites, spines, toxins, poisons, and associated infections also contribute to the incidence of nonfatal, but often debilitating, injuries in Gulf seafood workers. Animal-related hazards also include protein exposures to the dermal and respiratory systems, which are covered separately below.

Hornbeak and Auerbach warned that fishers were potentially exposed to venomous aquatic animal stings, bites, abrasions, and lacerations related to contact with venomous cnidaria, sponges, bristle worms, crown-of-thorns starfish, sea urchins, venomous fish, stingrays, cone snails, stonefish, blue-ringed octopus, and sea snakes. Their focus was to inform emergency responders of anti-venom administration, anaphylaxis treatment, and surgery as well as long-term treatment [28]. Forrester identified 153 stingray injuries that were reported to Texas poison centers from 1998 to 2004. Treatment of $61 \%$ of the cases occurred in non-healthcare facilities, and all these incidents resulted in harm, $53 \%$ of which were minor. According to the author, envenomation by stingrays is relatively common among fisherman, and injuries can be painful and cause complications such as nausea, vomiting, salivation, sweating, respiratory depression, muscle fasciculation, convulsions, edema, and ischemic necrosis [29]. 
Haddad determined that toxins from sponges, worms, mollusks, echinoderms, crustaceans, fish, and reptiles can have neurotoxic, proteolytic, myotoxic, hemotoxic (hemolytic), and cytotoxic effects [30]. Ottuso provided a similar review as shown below [31].

- Sponges are covered with an irritating slime and the sponge body has spikes that can enhance the damage and irritate skin from contact; this effect can last for up to two weeks.

- Some jellyfish and the Portuguese man-of-war have tentacles that can puncture and inoculate the skin and deliver venom causing envenomation with immediate toxic action with severe pain and either rapid or delayed allergic reaction.

- Marine worms can bite divers with powerful jaws and cause severe pain. Mussel harvesters come in contact with the worms, but rarely receive bites.

- Some single shell mollusks and gastropods can inject venom.

- Cone snails can inject a neurotoxin that induces neuromuscular blockage, progressive paralysis, and possible death.

- Some species of starfish, such as the crown of thorns, are venomous and sea urchins and sea cucumbers produce toxins that can cause irritations.

- Crustaceans can cause severe allergic reactions, contact dermatitis, and claw-related injuries.

Jeebhay et al. conducted a review of 108 studies of seafood allergy over the period 1978 to 2000 of fishers and processing workers that included dermal-associated allergies regarding exposures to crustaceans, mollusks, bony fish/finfish, and other seafood agents; and occupational, protein contact dermatitis; breaks in the intact skin barrier added risk to protein contact dermatitis. None of eight epidemiologic and case studies evaluated regarding contact dermatitis related to fishers but did relate to fish processors and fishmongers. Most of 23 epidemiologic and case studies regarding asthma reviewed related to fish processors. Four related to fishers including cuttlefish ( $1 \%$ incidence, $n=66$ ), abalone $(n=1)$, spiny lobster ( $9 \%$ asthma prevalence from red soft coral exposure), and one regarding anisakis exposure (nematode in fish) among fishers (Asthma prevalence $=18 \%, n-28$ ), and one related to sea squirt among oyster farmers ( $29 \%$ asthma prevalence, $n=1413)$ [32]. Sharp and Lopata examined finfish allergy and asthma (including exposure to trout, salmon, pilchard, anchovy, plaice, hake, tuna, haddock cod, and pollock) and found a prevalence of protein contact dermatitis at 3\% to $11 \%$ across these species. They identified the skin route of occupational exposure as unprotected handling (i.e., no gloves) [33].

\subsection{Skin Hazards}

Biological hazards described above included hazards to the skin. Fishers may experience other skin-related hazards, including cancerous and precancerous skin lesions, eczemas (dermatitis), superficial fungal infections, bacterial infections of the skin, traumatic skin injuries and infections, bites and stings, shocks from fish, and contact and skin problems related to environmental extremes. Acute exposure to solar radiation and resulting burns has been associated with occurrence of skin cancer.

Burke summarized cutaneous hazards faced by fishers and acknowledged the paucity of data on these hazards in this group of workers. He described hazardous exposures from ultraviolet radiation, environmental extremes, trauma, irritants and allergens, infectious agents, and dangerous or toxic marine fauna and flora [34].

Loddé et al. investigated fishers with contact dermatitis related to seafood protein (i.e., fish) exposure. Contact dermatitis is a blistering rash that becomes itchy after skin contact with protein and respiratory signs emerge indicating rhinitis or asthma. Fishers were considered at risk for this dermatitis. In this study, the researchers identified eight cases caused by contact with fish or crustaceans from among 145,293 registered medical cases involving contact with salmon, whiting, crustaceans, monkfish, scallops, and daphnia. Two other cases appeared to be irritant contact dermatitis. Surprisingly, none of the eight selected cases were fishers; seven were chefs and one worked in a 
pet shop. Underdiagnoses may occur for various reasons: fishers may not report the incidence or request compensation, they may find another occupation (the healthy worker effect) before the problem worsens (atopy sufferers may self-select to not fish), or they notice the problem and begin to wear gloves and other protective gear that may prevent future skin problems. Only fishers with serious cases of contact dermatitis may seek hospital care and, thus, be counted as having the condition [35]. Sridhar and Deo reported that common aquatic skin hazards include sunburn, hives (urticarial: itchy patch of skin that turns into swollen red welts), jellyfish stings, wound infections, and rubber contact allergic dermatitis related to diving equipment [36].

Staphylococcus bacterial infection from skin contact with fish slime can become serious if left untreated and allowed to become systemic in the lymphatic system. The National Oceanic and Atmospheric Administration (NOAA) warns its observers of the potential for cellulitis caused by fish slime. NOAA instructed their observers to wash their hands thoroughly with hot water and soap or an antiseptic (such as betadine or povidone iodine) after handling fish [37].

Burke et al. reported that in 81 volunteer fishers in North Carolina, seven (9\%) had at least one basal cell carcinoma and five $(6 \%)$ had at least one squamous cell carcinoma, although none had melanomas [38]. Strickland et al. examined the prevalence of nonmelanoma skin cancer among 808 Maryland watermen in relation to age and exposure to solar ultraviolet (UV) B radiation. Average annual exposure to UV radiation was strongly correlated with the prevalence of squamous cell carcinoma, but not with the prevalence of basal cell carcinoma or actinic keratosis [39].

Bezerra et al. conducted a study of 19 Brazilian fishers that included an evaluation of clinical, histological, and immunological effects of chronic exposure to solar UV radiation [40]. They made two comparisons: (1) fishers versus 10 non-fisher controls and (2) covered versus uncovered skin on the fisher cohort. The fishers' exposed skin showed increases in solar elastosis (appearance of yellow and thickened skin), melanosis (hyperpigmentation by excessive deposits of melanin), and hyperkeratosis (epidermis thickening). In the examination of covered versus uncovered skin of the fishers, exposed skin macrophages (solar elastosis, skin aging) were more predominate in the upper and middle layers around blood vessels adjacent to elastic material. Surprisingly, the fishers showed no premalignant or malignant neoplasia of the skin, which suggested that the body creates a defense mechanism with chronic and long-lasting solar radiation exposure that includes increased melanin in the bottom layer of the skin compared with skin undergoing only occasional exposure. The investigators referred to Schwartz who suggested this hypothesis [41] and to Lautenschlager et al., who supported the concept of "photoprotection" [42]. Systemic changes in immunological markers triggered by solar radiation in the fisher cohort and the control group were not different [40]. They did not address cancer of the eye or lips; other studies have found a higher incidence of lip cancer among fishers relative to the general population.

Piñera-Marques et al. evaluated lip lesions on Brazilian fishers as related to chronic solar radiation exposure [43]. The cohort included 125 Caucasian fishers (121 males and 4 females) and the control group had 30 Caucasians ( 28 males and 2 females) with indoor jobs and minimal sunlight exposure; both groups averaged 51 years of age. The fisher group averaged 32 years of sunlight exposure and a daily exposure of $7.7 \mathrm{~h}$. They found that the fisher population had a high prevalence of epithelial dysplasia (premalignant lesions) and malignant lesions of the lip. They also observed that the conditions were associated with a blurring of the vermilion margin (the sharp demarcation between the lip and adjacent normal skin) of the lower lip.

\subsection{Ocular Hazards}

“From sea to shining sea!"-Katharine Lee Bates, 1893 [44]

A 2016 systematic review considered five studies regarded vision impairment among marginalized fishing populations. The review found cataract as a significant problem, but disappointment was expressed regarding the few studies regarding the problem of eye health among fishers, including in high income countries [45]. However, the 1985 Chesapeake Bay Waterman study and many 
follow-up studies of ocular hazards to fish harvesters in Maryland identified several ocular diseases. While the original emphasis was on the effect of UV radiation on eye health, other findings emerged. One important finding was that macular degeneration was not associated with UV exposure but was associated with blue light exposure. Nonetheless, as shown in Table 2, UV exposure has significant effects on fish harvester eye health. Other afflictions that occur to the eyes of fish harvesters include ocular jellyfish stings [46].

Table 2. Ocular diseases among fish harvesters.

\begin{tabular}{|c|c|c|}
\hline Disease or Trauma & Hazard & Reference \\
\hline - Eye lid tumors & $\begin{array}{l}\text { Ultraviolet (UV) exposure among watermen } \ddagger \\
\text { strongly associated with squamous cell carcinoma } \\
\text { and not basal cell carcinoma * }\end{array}$ & $\begin{array}{l}\text { Strickland et al., } 1989 \text { [39]; } \\
\text { Yam and Kwok, } 2013 \text { [47] }\end{array}$ \\
\hline $\begin{array}{l}\text { - Actinic keratosis (scaly patch on } \\
\text { the skin) }\end{array}$ & $\begin{array}{l}\text { Significantly associated with UV radiation exposure } \\
\text { among watermen }\end{array}$ & Vitasa et al., 1990 [48] \\
\hline $\begin{array}{l}\text { - Climatic droplet keratopathy } \\
\text { (degenerative condition of the cornea) }\end{array}$ & $\begin{array}{l}\text { Significantly associated with chronic UV radiation } \\
\text { exposure among watermen }\end{array}$ & Taylor et al., 1989 [49] \\
\hline $\begin{array}{l}\text { - Pterygium (surfers' eye: fleshy mass } \\
\text { that grows over part of the cornea) }\end{array}$ & $\begin{array}{l}\text { "Strongly" associated with UV exposure } \\
\text { among watermen }\end{array}$ & $\begin{array}{l}\text { Taylor et al., } 1989 \text { [49]; } \\
\text { Wong et al., } 1993 \text { [50]; } \\
\text { Lai and Ho, } 1994 \text { [51] }\end{array}$ \\
\hline $\begin{array}{l}\text { - Pinguecula (yellowish spot on either } \\
\text { side of the cornea) }\end{array}$ & $\begin{array}{l}\text { Weak association among watermen with } \\
\text { UV exposure }\end{array}$ & Taylor et al., 1989 [49] \\
\hline $\begin{array}{l}\text { - Photokeratitis (snow blindness: } \\
\text { acute painful eye condition caused by } \\
\text { exposure to UV rays) }\end{array}$ & $\begin{array}{l}\text { Frequency is high for acute reflected UV causing } \\
\text { "excruciating" eye pain that will resolve within } \\
24-48 \mathrm{~h}\end{array}$ & $\begin{array}{l}\text { Rosenthal, et al., } 1988 \text { [52]; } \\
\text { Yam and Kwok, } 2013 \text { [47]; } \\
\text { Moore et al., } 2010 \text { [53] }\end{array}$ \\
\hline $\begin{array}{l}\text { - Cataract (clouding of the eye's } \\
\text { natural lens) }\end{array}$ & $\begin{array}{l}\text { Cataract formation among watermen "firmly" linked } \\
\text { to UV exposure }\end{array}$ & $\begin{array}{l}\text { Taylor et al., } 1988 \text { [54]; } \\
\text { Schein et al., } 1994 \text { [55] }\end{array}$ \\
\hline $\begin{array}{l}\text { - Macular degeneration (distortion or } \\
\text { loss of central vision) }\end{array}$ & $\begin{array}{l}\text { No association with UV exposure, but there is an } \\
\text { association among watermen with blue } \\
\text { light exposure }\end{array}$ & $\begin{array}{l}\text { West et al., } 1989 \text { [56]; } \\
\text { Taylor et al., } 1992[57]\end{array}$ \\
\hline - Uveal (ocular) melanoma & No association found to sunlight exposure & Yam and Kwok 2013 [47] \\
\hline
\end{tabular}

\subsection{Breathing Hazards}

In their study of fishers and processing workers, Jeebhay et al. identified a prevalence of occupational asthma at $7 \%$ to $36 \%$, respectively [32]. Sharp and Lopata identified the inhalation route of exposure to wet aerosols from fish handling, degutting, and boiling during processing to be linked to an occupational asthma prevalence of $7 \%$ to $8 \%$ [33]. However, while Lucas et al. found that asthma resulting from processing or cooking of crabs, prawns, and trout can create airborne allergens, they concluded that asthma is rare among fishers, likely because of adequate ventilation. Research has identified sodium disulfite, used to store fish and seafood, exposure as a cause of asthma. Allergic reactions can also result from exposure to antifouling paints containing fungicides such as chlorothalonil; cleaning products that contain ammonium compounds, chloramine, and Chloramine-T; and diesel engine exhaust [27]. Lucas et al. described sodium metabisulfite a significant asthma hazards among mariners including fishers [58], which Durborow also addressed regarding fishers and fish farmers [59]. Sharp and Lopata also found that some physical factors (such as cold air and high physical activity) may trigger respiratory symptoms [33].

Divers in the fishing industry engage in harvesting shellfish and maintaining and repairing vessel hulls and piers. In addition to drowning, they face other significant breathing hazards that include decompression sickness, cerebral arterial gas embolism, compression pains, barotrauma, oxygen toxicity, hypoxia, and breathing gas contamination (e.g., carbon monoxide) [60]. 


\subsection{Hearing Hazards}

The USCG and the US Occupational Safety and Health Administration (OSHA) have similar noise standards except the USCG requires hearing protection at $85 \mathrm{~A}$-weighted decibels (dBA) and OSHA requires action level protection at $90 \mathrm{dBA}$ (time-weighted average) for hearing protection. The National Institute for Occupational Safety and Health (NIOSH) recommends an exposure limit of $85 \mathrm{dBA}$, but also recognizes that hearing damage occurs at lower levels.

Levin et al. conducted a survey of and audiometric testing on 227 Gulf Coast fishers. Most worked more than $16 \mathrm{~h}$ per shift. Noise-induced hearing loss was associated with years of fishing and not age. They measured engine room noise at 94.8 to $105.0 \mathrm{dBA}$ [61].

Neitzel et al. measured noise levels in the engine room of two catcher/processor vessels; the mean was $102 \mathrm{dBA}$ and the range was 74-114 dBA. Workers reported using earmuffs, two ear plugs, or a combination of both. Workers' hearing protection was not worn on an average of 70 min during a shift, and earmuffs were worn on average one hour longer than earplugs [62]. That study referred to another study of small fishing vessels with noise exposure from 56 to $110 \mathrm{dBA}$ by Martinis [63] and to measurements made by Axelsson and Clark in sleeping quarters located above the engine room where noise levels can exceed 85 dBA [64]. In another study, on an oceangoing dredging vessel, Bowes and Corn measured an average engine room noise level of $100 \mathrm{dBA}$ [65].

Paini et al. measured the loudest sound aboard small-scale shrimping vessels under full engine power while pulling nets $(n=141)$. Most fishers working boats with no engines had normal hearing, but subjects on vessels with engines had higher impaired hearing than age and gender-matched controls of other workers. None of the subjects wore hearing protectors [66]. Continuous noise and ototoxic agents (such as carbon monoxide) may contribute to hearing loss.

Kaerlev et al. found that engine room workers on Danish fishing vessels suffered hearing impairment, but other crewmembers had occupational hearing loss no different from a comparable population of onshore workers. Exposure levels were 102-110 dB in the engine room and $75-85 \mathrm{~dB}$ in the working and living areas [67]. Mantysalo and Vuori expressed the need to investigate continuous noise (e.g., sleeping quarters near engine rooms on small vessels) and impulse noise (e.g., crashing sounds during fishing operations) aboard vessels [68].

Barnes et al. and Voorhees and Barnes measured noise levels from moving water at two indoor tanks in aquaculture buildings. All the noise levels measured below the NIOSH recommended limit of $85 \mathrm{dBA}$ with the highest level measured at $83 \mathrm{dBA}$ recorded close to the rearing pavilion power source. They suggested even these lower noise levels may lead to other adverse effects, including elevated blood pressure, reduced performance, sleeping difficulties, annoyance, stress, and temporary threshold shift $[69,70]$.

\subsection{Near Shore Mariculture Hazards}

Moreau and Neis conducted a comprehensive review that covered hatcheries, nurseries, and grow-out production and the acute and chronic injury and potential health effects related to mariculture work processes. The hatcheries were land-based, but the nursery or grow-out phases can be either land-based or offshore benthic culture. The hazards included those related to work design (ergonomics) and exposures to the skin or respiratory system. Onshore hazards included slips and trips, falls, travel, machinery, electricity, fires, and noise. Offshore hazards presented similar problems as fishing hazards, but at a smaller scale and included temperature extremes [71]. Biological hazards were present both onshore and offshore. Mitchell described the frequency of mariculture-related illnesses from a Norway study during the 1980-1999 period that included musculoskeletal disorders $(n=8)$, skin allergies $(n=8)$, hearing loss $(n=4)$, and asthma, poisoning, and allergic reaction at one each [72].

Guertler et al. reported on the main risks faced by Brazilian workers in shellfish (oyster) mariculture as [73]: 
- (1) noise or electric shock from the wash machine and high pressure washer; (2) the sun's ultraviolet radiation; (3) cold or warm conditions, humidity, rain, water, and water used in cleaning; (4) cuts from equipment or shellfish; (5) slips, trips, and falls on the boat, wet and slippery floors, and shellfish discard on the floor, (6) drowning; (7) biological exposures from rodents, insects, snakes, and aquatic animals; (8) inadequate posture related to tools and workplace layout; and (9) manual material handling and lifting excessive weight.

- A pain perception analysis over a 12-month period of nine oyster mariculturists resulted in the highest pain complaints made at the shoulder $(62 \%)$ followed by lower back $(50 \%)$; wrists, hands, and fingers (38\%); upper back (38\%); neck (25\%); elbows (12\%); forearm (12\%); hips and thighs $(12 \%)$; and knees (12\%).

Mitchell reported the dominant risk factor regarding near-shore mariculture in Australia for fatalities was climatic and environmental hazards. Beyond fatalities, other significant hazards were musculoskeletal disorders associated with manual lifting, falling against a solid object, and solar radiation exposure. Next in importance was mechanical, biological, psychological, noise, and vibration hazards, followed by stored energy hazards of electricity and chemical agents [72].

\section{Discussion}

The review identified studies that examined health risks with a focus on two of three criteria: severity in the individual case and frequency of the condition. A third criterion, preventability, will be addressed in a subsequent review article regarding interventions.

\subsection{Limitations}

Four limitations in the review are as follows. First, the literature recognized serious underreporting of some afflictions (such as aquatic animal hazards) across all vessel types. The second limitation is the lack of occupational health data specific to the GoM. Third, the literature omits evaluations of fisher mental health, which is related to the problem of fatigue and perhaps alcohol consumption at sea. Fourth, this is not a systematic review, but it is comprehensive across much subject matter.

\subsection{Implications of the Hazards}

The review identified known hazards associated with the types of occupational disorders and diseases that exist or may exist among GoM fish harvesters and mariculturists. The most severe problems identified were pain (back, shoulder, hands, and wrist), anaphylaxis from animal stings, skin cancer from solar radiation, staph infection from injury or animal bites, asthma from engine exhaust exposure, impaired hearing from engine noise, and multiple solar radiation effects on the eyes (cancer, cataract, actinic keratosis, and photo keratitis).

\subsubsection{Musculoskeletal Disorder Hazards}

Many studies around the world have addressed the problem of musculoskeletal disorders and pain associated with fishing. The universal problem is back pain, especially in the lumbar region. Other body parts affected included the shoulder (e.g. rotator cuff), hands and wrists (i.e., carpal tunnel), elbows, and knees. Lifting and pulling heavy loads, bending, and twisting are sources of most of these problems. Repetitive, awkward motions also aggravate musculoskeletal health.

\subsubsection{Aquatic Animal Hazards}

Biological hazards include asthma and allergy, venomous bites and stings, and, most life-threatening, envenomation from toxic animal bites. Dangerous animals include certain jellyfish, stingrays, sea snakes, the Portuguese man-of-war, and certain marine snails. Little research has been conducted in this area. 


\subsubsection{Skin Hazards}

Hazards to the skin include some of the biological hazards, such as allergic contact dermatitis and irritant contact dermatitis. Skin cancer was reviewed as an obvious hazard, but surprisingly, people who are exposed continually over a prolonged period may develop protective barriers to cancer called photoprotection. However, sunburns need to be avoided (e.g., new deckhands and occasional exposures of mariculturists), and lips and eyes do not offer this photoprotection.

\subsubsection{Ocular Hazards}

The principle ocular hazard is exposure to solar UV radiation and is related to several potential diseases. Exposures that reflect UV sunlight from the water surface presents an acute eye hazard, photokeratitis, aka snow blindness, as does ocular jellyfish stings.

\subsubsection{Breathing Hazards}

Fishers are at risk of asthma if exposed to airborne protein aerosols from fish, but this is rare for work is on deck where adequate ventilation is usually part of the working environment. Processing fish, including gutting, within enclosed areas on the vessel or on land increases this risk of breathing hazards. Other exposures, such as fish preservation materials and defouling agents when applied to the boat, may also present respiratory hazards. Diving presents obvious and unique hazards to breathing.

\subsubsection{Hearing Hazards}

Hazardous noise from vessel engines is a uniform hazard around the world for all vessels no matter the size. The heavier the load on the engine, the louder the noise. Onboard sleeping quarters may expose fishers to engine noise. Carbon monoxide exposure is also toxic to hearing.

\subsubsection{Near Shore Mariculture Hazards}

Clam mariculture involves both onshore and offshore hazards. Onshore hazards involve the production facilities for juveniles and the sizing and cleaning of the after-harvest adults. Hazards include musculoskeletal stresses, electric shock, slips and trips, noise, aquatic animal and rodent contact, and falling objects. Offshore operations involve the setting and retrieval of grow out bags of clams that contribute to musculoskeletal stress and the hazard of stepping on dangerous aquatic animals. Skiffs used offshore have been involved in vessel-related disasters.

\section{Conclusions}

Based on studies outside of the GoM, musculoskeletal disorders are likely a high-frequency problem among GoM fishers. Much less is known about other health-related problems in the GoM, which include poisoning from aquatic animals, dermatitis, cancer, hearing loss, and respiratory problems. Other mortality and morbidity-related problems, such as chronic and emergency health conditions (e.g., heart attacks), have received little research. Thus, population-based studies of the hazards for the fisher population would aid in targeting interventions across a broader range of maladies.

The fishing community is known for "working through pain" and not seeking medical help for injuries or illnesses unless severe. The healthy worker effect may be rampant as indicated. Thus, many injuries and illnesses remain underreported, especially among fishers on small vessels.

The fishing industry employs several interventions to avoid injuries, such as protective gloves that serve as a barrier not only to trauma injury but to protein-related allergens as well. (This protection was often not used among seafood chefs, who experience more such incidents). Moreover, adequate ventilation by working on deck may also result in protection against asthma from bioaerosol exposures in contrast with a high incidence of asthma among seafood processors who do not have that "outdoor" advantage. A surprise finding in the literature was that fishers who are chronically and continuously 
exposed to solar radiation may develop protection against skin cancer known as "photoprotection", whereas those with less exposure may actually be more vulnerable to skin cancers. A companion review article will address known interventions related to work-related injuries as well as illnesses identified in this article.

Author Contributions: M.L.M. conducted the search and initial composition of the manuscript. R.M.D. and A.S.K. provided ongoing reviews and edits of the manuscript, and A.S.K. directed the project.

Funding: The US National Institute for Occupational Safety and Health, Centers for Disease Control and Prevention funded this research through a grant to the University of Florida Southeastern Coastal Center for Agricultural Safety and Health, Gainesville, Florida, USA.

Acknowledgments: We acknowledge Christina McManus, Science and Technology Editor, Kentucky State University, Frankfort, Kentucky, USA for her technical edit of this manuscript.

Conflicts of Interest: The authors declare no conflicts of interest

\section{Appendix A. Literature Reviewed}

Table A1. The geographic origin (area) of the study and topic, the health problem, and a reference to the literature source, $n=52$.

\begin{tabular}{|c|c|c|}
\hline Area and Topic & Problem & Source \\
\hline \multicolumn{3}{|c|}{ Gulf of Mexico, $n=2$} \\
\hline Marine & Sting ray injuries & Forrester 2005 [29] \\
\hline Fishing & Noise & Levin et al., 2016 [61] \\
\hline \multicolumn{3}{|c|}{ Atlantic Coast USA, $n=19$} \\
\hline Fishing & Cataract & Taylor et al., 1988 [54] \\
\hline Fishing & Macular degeneration & West et al., 1989 [56] \\
\hline Fishing & Acute eye disease & Rosenthal et al., 1988 [52] \\
\hline Fishing & Eye lid tumors & Strickland et al., 1989 [39] \\
\hline Fishing & Eye disease & Taylor et al., 1989 [49] \\
\hline Fishing & Eye disease & Vitasa et al., 1990 [48] \\
\hline Fishing & Macular degeneration & Taylor et al., 1992 [57] \\
\hline Fishing & Ocular jellyfish sting & Glasser et al., 1992 [45] \\
\hline Fishing & Cataract & Schein et al., 1994 [55] \\
\hline Fishing & Skin diseases & Burke 1997 [34] \\
\hline Fishing (MA) & Musculoskeletal disorders & Fulmer and Buchholz 2002 [24] \\
\hline Fishing (NC) & Musculoskeletal disorders & Lipscomb et al., 2004 [23] \\
\hline Fishing (NC) & Skin disorders & Burke et al., 2006 [38] \\
\hline Crab and gillnet fishing (NC) & Musculoskeletal disorders & Kucera et al., 2008 [19] \\
\hline Crab and gill net fishing (NC) & Low back pain & Kucera et al., 2009 [20] \\
\hline Fishing 0 & Acute eye disease & Moore et al., 2010 [53] \\
\hline Crab (NC) & Shoulder stress & Kucera and Lipscomb 2010 [21] \\
\hline Fishers, crab (NC) & Musculoskeletal disorders & Mirka et al., 2011 [13] \\
\hline Lobster (ME and MA) & Musculoskeletal pain & Fulmer et al., 2017 [25] \\
\hline \multicolumn{3}{|c|}{ Alaska USA, $n=1$} \\
\hline Fishing & Noise exposure & Neitzel et al., 2006 [62] \\
\hline \multicolumn{3}{|c|}{ Brazil, $n=5$} \\
\hline Fishing & Noise & Paini et al., 2009 [66] \\
\hline Fishing & Lip cancer & Piñera-Marques et al., 2010 [43] \\
\hline Aquatic & Zoonotic injury & Haddad 2013 [30] \\
\hline Oyster culture & Musculoskeletal disorders & Guertler et al., 2016 [73] \\
\hline Fishing & Solar radiation exposure & Bezerra et al., 2011 [40] \\
\hline \multicolumn{3}{|c|}{ Spain and France, $n=3$} \\
\hline Maritime & Asthma & Lucas et al., 2006 [27] \\
\hline French fishing & Asthma & Lucas et al., 2016 [58] \\
\hline Fishing & Contact dermatitis & Loddé et al., 2017 [35] \\
\hline
\end{tabular}


Table A1. Cont.

\begin{tabular}{|c|c|c|}
\hline Area and Topic & Problem & Source \\
\hline \multicolumn{3}{|c|}{ Australia and New Zealand, $n=2$} \\
\hline Mariculture & Several disorders & Mitchell 2002 [72] \\
\hline Fish & Allergy & Sharp and Lopata 2013 [33] \\
\hline \multicolumn{3}{|c|}{ Northern Europe, $n=4$} \\
\hline Fishing & Ergonomics & Törner et al., 1988 [22] \\
\hline Fishing & Hearing loss & Kaerlev et al., 2008 [67] \\
\hline Fishing & Musculoskeletal disorders & Kaerlev et al., 2008 [26] \\
\hline Fishing & Skin and infectious diseases & Kaerlev et al., 2014 [12] \\
\hline \multicolumn{3}{|c|}{ Other, $n=16$} \\
\hline US fishing & Hearing loss & Martinis 1977 [63] \\
\hline Fishing & Noise & Mantysalo and Vuori 1984 [68] \\
\hline China & Eye disease & Wong et al., 1993 [50] \\
\hline China & Eye disease & Lai and Ho, $1994[51]$ \\
\hline US unserved cohorts & Hearing loss & Axelsson and Clark 1995 [64] \\
\hline Diving & Hazards & Thalmann 1997 [60] \\
\hline Fishing & Noise & Bowes and Corn 1990 [65] \\
\hline Seafood & Dermatitis, asthma & Jeebhay et al., 2001 [32] \\
\hline Fishing and aquaculture & Hazardous exposures & Durborow 1999 [59] \\
\hline Canada aquaculture & Health and safety hazards & Moreau and Neis 2009 [71] \\
\hline US Observers & Poisoning, infection & NOAA 2010 [37] \\
\hline China & Ocular diseases & Yam and Kwok 2013 [47] \\
\hline US (SD) finfish & Aquaculture noise & Barnes et al., 2015 [69] \\
\hline India & Dermal hazards & Sridhar and Deo 2017 [36] \\
\hline US (SD) finfish & Aquaculture noise & Voorhees and Barnes 2017 [70] \\
\hline US & Marine envenomation & Hornbeak and Auerbach 2017 [28] \\
\hline
\end{tabular}

\section{References}

1. Carruth, A.K.; Levin, K.J.; Gilmore, K.; Bui, T.; Gallardo, G.; Evert, W.; Sealey, L. Cultural influences on safety and health education among Vietnamese fishermen. J Agromed. 2010, 15, 375-385. [CrossRef] [PubMed]

2. Myers, M.; Kane, A.; Durborow, R. Gulf of Mexico seafood harvesters: Part 1. Occupational injury risk factors. Safety 2018, in press.

3. Myers, M.; Durborow, R.; Kane, A. Gulf of Mexico seafood harvesters: Part 3. Potential occupational risk reduction measures. Safety 2018, in press.

4. Rafnsson, V. Health Problems and Disease. In Encyclopedia of Occupational Health and Safety, 4th ed.; International Labor Office: Geneva, Switzerland, 1998; Volume III, pp. 66.14-66.17.

5. Olafsdottir, H. Musculoskeletal Disorders among Fishermen and Worker in the Fish Processing Industry. In Encyclopedia of Occupational Health and Safety, 4th ed.; Labor Office: Geneva, Switzerland, 1998; Volume III, pp. 66.17-66.18.

6. Frantzeskou, E.; Jensen, O.; Linos, A. Prevalence of health risk factors among fishermen-A review. Occup. Med. Health Aff. 2014, 2. [CrossRef]

7. Matheson, C.; Morrison, E.; Murphy, E.; Lawrie, T.; Ritchie, R.; Bond, C. The health of fishermen in the catching sector of the fishing industry: A gap analysis. Occup. Med. 2001, 51, 305-311. [CrossRef]

8. Conway, G.A.; RaLonde, R. Fish Farming and Aquaculture. In Encyclopedia of Occupational Health and Safety, 4th ed.; Labor Office: Geneva, Switzerland, 1998; pp. 33-34.

9. Levin, J.L.; Gilmore, K.; Shepherd, S.; Wickman, A.; Carruth, A.; Nalbone, J.T.; Gallardo, G.; Nonnenmann, M.W. Factors influencing safety among a group of commercial fishermen along the Texas Gulf Coast. J Agromed. 2010, 15, 363-374. [CrossRef] [PubMed]

10. Janocha, J. Facts of the catch: Occupational illnesses, injuries and fatalities to fishing workers 2003-2009. Beyond the Numbers: Workplace Injuries; US Bureau of Labor Statistics: Washington, DC, USA, 2012; Volume 1, pp. 1-7. Available online: https://www.bls.gov/opub/btn/volume-1/pdf/facts-of-the-catch-occupationalinujuries-in-fishing-industries.pdf (accessed on 1 June 2017).

11. Chauvin, C.; Le Bouar, G.; Salim, L. Analysis of occupational injuries in the sea fishing industry according to the type of fishery and the fishing activity. Int. Marit. Health 2017, 68, 31-38. [CrossRef] [PubMed] 
12. Kaerlev, L.; Jensen, A.; Hannerz, H. Surveillance of hospital contacts among Danish seafarers and fishermen with a focus on skin and infectious diseases-A population-based cohort study. Int. J. Environ. Res. Public Health 2014, 11, 1931-11949. [CrossRef] [PubMed]

13. Mirka, G.A.; Ning, X.; Jin, S.; Haddad, O.; Kucera, K.L. Ergonomic intervention for commercial crab fishermen. Int. J. Ind. Ergon. 2011, 41, 481-487. [CrossRef]

14. Törner, M.; Blide, G.; Eriksson, H.; Kadefors, R.; Karlsson, R.; Petersen, I. Musculoskeletal symptoms as related to working conditions among Swedish professional fishermen. Appl. Ergon. 1988, 19, 191-201. [CrossRef]

15. Norrish, A.; Cryer, P. Work related injury in New Zealand commercial fishermen. Br. J. Ind. Med. 1990, 47, 726-732. [CrossRef] [PubMed]

16. Jensen, O. Work related injuries in Danish fishermen. Occup. Med. 1996, 46, 414-420. [CrossRef]

17. Chauvin, C.; Le Bouar, G. Occupational injury in the French sea fishing industry: A comparative study between the 1980s and today. Accid. Anal. Prev. 2007, 39, 79-85. [CrossRef] [PubMed]

18. Antão, P.; Almeida, T.; Jacinto, C.; Soares, C.G. Causes of occupational accidents in the fishing sector in Portugal. Saf. Sci. 2008, 46, 885-899. [CrossRef]

19. Kucera, K.L.; Mirka, G.A.; Loomis, D.; Marshall, S.W.; Lipscomb, H.J.; Daniels, J. Evaluating ergonomic stresses in North Carolina commercial crab pot and gill net fishermen. J. Occup. Environ. Hyg. 2008, 5, 182-196. [CrossRef] [PubMed]

20. Kucera, K.L.; Loomis, D.; Lipscomb, H.J.; Marshall, S.W.; Mirka, G.; Daniels, J. Ergonomic risk factors for low back pain in North Carolina crab pot and gillnet commercial fishermen. Am. J. Ind. Med. 2009, 52, 311-321. [CrossRef] [PubMed]

21. Kucera, K.L.; Lipscomb, H.J. Assessment of physical risk factors for the shoulder using the Posterior, Activity, Tools, and Handling (PATH) method in small-scale commercial crab pot fishing. J. Agromed. 2010, 15, 394-404. [CrossRef] [PubMed]

22. Törner, M.; Blide, G.; Eriksson, H.; Kadefors, R.; Karlsson, R.; Petersen, I. Workload and ergonomics measures in Swedish professional fishing. Appl. Ergon. 1988, 19, 202-212. [CrossRef]

23. Lipscomb, H.J.; Loomis, D.; McDonald, M.A.; Kucera, K.; Marshall, S.; Li, L. Musculoskeletal symptoms among commercial fishers in North Carolina. Appl. Ergon. 2004, 35, 417-426. [CrossRef] [PubMed]

24. Fulmer, S.; Buchholz, B. Ergonomic exposure case studies in Massachusetts fishing vessels. Am. J. Ind. Med. 2002, 42, 10-18. [CrossRef] [PubMed]

25. Fulmer, S.; Buchholz, B.; Scribani, M.; Jenkins, P. Musculoskeletal disorders in Northeast lobstermen. Saf. Health Work 2017, 1-8. [CrossRef] [PubMed]

26. Kaerlev, L.; Jensen, A.; Nielsen, P.S.; Olsen, J.; Hannerz, H.; Tüchsen, F. Hospital contacts for injuries and musculoskeletal diseases among seamen and fishermen: A population-based cohort study. BMC Musculoskelet. Disord. 2008, 9, 1-9. [CrossRef] [PubMed]

27. Lucas, D.; Jegaden, D.; Lodde, B.; Arvieux, C.; Dewitte, J.-D. Occupational asthma in maritime environment. Int. Marit. Health 2006, 57, 177-187. Available online: https:/ /imh.mug.edu.pl/attachment/attachment/ 5264/R17.pdf (accessed on 10 June 2017). [PubMed]

28. Hornbeak, K.B.; Auerbach, P.S. Marine envenomation. Emerg. Med. Clin. N. Am. 2017, 35, 321-337. [CrossRef] [PubMed]

29. Forrester, M.B. Patterns of stingray injuries reported to Texas poison centers from 1998 to 2004. Hum. Exp. Toxicol. 2005, 24, 639-642. [CrossRef] [PubMed]

30. Haddad, V. Environmental dermatology: Skin manifestations of injuries caused by invertebrate aquatic animals. An. Bras. Dermatol. 2013, 88, 496-506. [CrossRef] [PubMed]

31. Ottuso, P. Aquatic dermatology: Encounters with the denizens of the deep (and not so deep) a review. Part I: The invertebrates. Int. J. Dermol. 2013, 52, 136-152. [CrossRef] [PubMed]

32. Jeebhay, M.F.; Robins, T.G.; Lehrer, S.B.; Lopata, A.L. Occupational seafood allergy: A review. Occup. Environ. Med. 2001, 58, 553-562. [CrossRef] [PubMed]

33. Sharp, M.F.; Lopata, A.L. Fish allergy: In review. Clin. Rev. Allergy Immunol. 2013, 46, 258-271. [CrossRef] [PubMed]

34. Burke, W.A. Skin diseases in fishermen. In Safety and Health in Agriculture, Forestry, and Fisheries; Langley, R.L., McLymore, R.L., Meggs, W.J., Roberson, G.T., Eds.; Government Institutes: Rockville, MD, USA, 1997; pp. 681-712. 
35. Loddé, B.; Cros, P.; Roguedas-Contios, A.M.; Pougnet, R.; Lucas, D.; Dewitte, J.D.; Misery, L. Occupational contact dermatitis from protein in sea products: Who is the most affected, the fisherman or the chef? J. Occup. Med. Toxicol. 2017, 12, 1-6. [CrossRef] [PubMed]

36. Sridhar, J.; Deo, R. Marine and other aquatic dermatoses. Indian J. Dermatol. 2017, 62, 66-78. Available online: http:/ / www.e-ijd.org/text.asp?2017/62/1/66/198052 (accessed on 30 June 2017). [CrossRef] [PubMed]

37. National Oceanic and Atmospheric Administration (NOAA). Observer Training Manual; National Marine Fisheries Service Southeast Fisheries Science Center Galveston Laboratory: Galveston, TX, USA, September 2010; p. 22. Available online: https:/ /www.st.nmfs.noaa.gov/Assets/Observer-Program/pdf/Shrimp_ Reef_Fish_Manual_9_22_10.pdf (accessed on 16 June 2017).

38. Burke, W.A.; Griffith, D.C.; Scott, C.M.; Howell, E.R. Skin problems related to the occupation of commercial fishing in North Carolina. N. C. Med. J. 2006, 67, 260-265. [PubMed]

39. Strickland, P.T.; Vitasa, B.C.; West, S.; Rosenthal, F.S.; Emmett, E.A.; Taylor, H.R. Quantitative carcinogenicity in man: Ultraviolet dose-dependence of skin cancer in Maryland watermen. J. Cancer Inst. 1989, 81, 1910-1913. [CrossRef]

40. Bezerra, S.M.; Sotto, M.N.; Orii, N.M.; Alves, C.; Duarte, A.J. Effects of long-term chronic exposure to sun radiation in immunological system of commercial fishermen in Recife, Brazil. An. Bras. Dermatol. 2011, 86, 222-233. [CrossRef] [PubMed]

41. Schwartz, T. Mechanisms of UV-induced immunosuppression. Keio J. Med. 2005, 54, 167-171. [CrossRef]

42. Lautenschlager, S.; Dandie, G.W.; Muller, H.K. Photoprotection. Lancet 2007, 370, 528-537. [CrossRef]

43. Piñera-Marques, K.; Lorenco, S.V.; Silva, I.F.F.; Sotto, M.N.; Carneiro, P.C. Actinic lesions in fishermen's lower lip: Clinical, cytopathological and histopathologic analysis. Clinics 2010, 65, 363-367. [CrossRef] [PubMed]

44. Ponder, M.M. Katherine Lee Bates: From Sea to Shining Sea; Windy City Publishers: Rolling Meadows, IL, USA, 2017.

45. Ahmad, K.; Zwi, A.; Tarantola, D.J.; Chand, B. A systematic review of epidemical literature on the eye health of marginalized fishing populations. JPMA J. Pak. Med. Assoc. 2016, 66, S81-S82. Available online: http:/ / ecommons.aku.edu/pakistan_fhs_mc_surg_surg/103 (accessed on 1 November 2017).

46. Glasser, D.B.; Noell, M.J.; Burnett, J.W.; Kathuria, S.S.; Rodrigues, M.M. Ocular jellyfish stings. Ophthalmology 1992, 99, 1414-1418. [CrossRef]

47. Yam, J.C.; Kwok, A.K. Ultraviolet light and ocular diseases. Int. Ophthalmol. 2014, 34, 383-400. [CrossRef] [PubMed]

48. Vitasa, B.C.; Taylor, H.R.; Strickland, P.T.; Rosenthal, F.S.; West, S.; Abbey, H.; Ng, S.K.; Munoz, B.; Emmett, E.A. Association of non-melanoma skin cancer and actinic keratosis with cumulative solar ultraviolet exposure in Maryland watermen. Cancer 1990, 65, 2811-2817. [CrossRef]

49. Taylor, H.R.; West, S.K.; Rosenthal, F.S.; Munoz, B.; Newland, H.S.; Emmett, E.A. Corneal changes associated with chronic UV irradiation. Arch. Ophthalmol. 1989, 107, 1481-1484. [CrossRef] [PubMed]

50. Wong, L.; Ho, S.C.; Coggon, D.; Cruddas, A.M.; Hwang, C.H.; Ho, C.P.; Robertshaw, A.M.; MacDonald, D.M. Sunlight exposure, antioxidant status, and cataract in Hong Kong fishermen. J. Epidemiol. Community Health 1993, 47, 46-49. Available online: https:/ / www.jstor.org/stable/25567671?seq=1\#page_scan_tab_contents (accessed on 1 November 2017). [CrossRef] [PubMed]

51. Lai, J.S.M.; Ho, P.C.P. Pterygium in Hong Kong fishermen. J. Hong Kong Med. Assoc. 1994, 46, 16-18.

52. Rosenthal, F.S.; Phoon, C.; Bakalian, A.E.; Taylor, H.R. The ocular dose of ultraviolet radiation to outdoor workers. Investig. Ophthalmol. Vis. Sci. 1988, 29, 649-656.

53. Moore, L.A.; Hussey, M.; Ferreira, J.T.; Wu, B. Review of photokeratitis: Corneal response to ultraviolet radiation (UVR) exposure. S. Afr. Optom. 2010, 69, 123-131. [CrossRef]

54. Taylor, H.R.; West, S.K.; Rosenthal, F.S.; Muñoz, B.; Newland, H.S.; Abbey, H.; Emmett, E.A. Effect of ultraviolet radiation on cataract formation. N. Engl. J. Med. 1988, 319, 1429-1433. [CrossRef] [PubMed]

55. Schein, O.D.; West, S.; Munoz, B.; Vitale, S.; Maguire, M.; Taylor, H.R.; Bressler, N.M. Cortical lenticular opacification: Distribution and location in a longitudinal study. Investig. Ophthalmol. Vis. Sci. 1994, 35, 363-366.

56. West, S.K.; Rosenthal, F.S.; Bressler, N.M.; Bressler, S.B.; Munoz, B.; Fine, S.L.; Taylor, H.R. Exposure to sunlight and other risk factors for age-related macular degeneration. Arch. Ophthalmol. 1989, 107, 875-879. [CrossRef] [PubMed] 
57. Taylor, H.R.; West, S.; Muñoz, B.; Rosenthal, F.S.; Bressler, S.B.; Bressler, N.M. The long-term effects of visible light on the eye. Arch. Ophthalmol. 1992, 110, 99-104. [CrossRef] [PubMed]

58. Lucas, D.; Loddé, B.; Jepsen, J.R.; Dewitte, J.D.; Jégaden, D. Occupational asthma in maritime environments. Internat. Marit. Health 2016, 67, 144-152. [CrossRef] [PubMed]

59. Durborow, R.M. Health and safety concerns in fisheries and aquaculture. Occup. Med. Stat. Art Rev. 1999, 14, 373-406.

60. Thalmann, E.D. Diving hazards. In Safety and Health in Agriculture, Forestry, and Fisheries; Langley, R.L., McLymore, R.L., Meggs, W.J., Roberson, G.T., Eds.; Government Institutes: Rockville, MD, USA, 1997; pp. 617-641.

61. Levin, J.L.; Curry, W.F.; Shepherd, S.; Nalbone, J.T.; Nonnenmann, M.W. Hearing loss and noise exposure among commercial fishermen in the Gulf Coast. J. Occup. Environ. Med. 2016, 58, 306-313. [CrossRef] [PubMed]

62. Neitzel, R.L.; Berna, B.E.; Seixas, N.S. Noise exposures aboard catcher/processor fishing vessels. Am. J. Ind. Med. 2006, 49, 624-633. [CrossRef] [PubMed]

63. Martinis, V.A. The Noise Profile and Hearing Levels of Commercial Fishermen. Master's Thesis, Department of Environmental Health, University of Washington, Seattle, WA, USA, 1977.

64. Axelsson, A.; Clark, W. Hearing conservation programs for nonserved occupations and populations. Occup. Med. 1995, 10, 657-662. [PubMed]

65. Bowes, S.M.; Corn, M. Noise exposure reduction aboard an oceangoing hopper dredge. Am. Ind. Hyg. Assoc. J. 1990, 51, 469-474. [CrossRef] [PubMed]

66. Paini, M.C.; Morata, T.C.; Corteletti, L.J.; Albizu, E.; Marques, J.M.; Santos, L. Audiological findings among workers from Brazilian small-scale fisheries. Ear Hear. 2009, 30, 8-15. [CrossRef] [PubMed]

67. Kaerlev, L.; Jensen, A.; Nielsen, P.S.; Olsen, J.; Hannerz, H.; Tüchsen, F. Hospital contacts for noise-related hearing loss among Danish seafarers and fishermen: A population-based cohort study. Noise Health 2008, 10, 41-45. [CrossRef] [PubMed]

68. Mantysalo, S.; Vuori, J. Effects of impulse noise and continuous steady state noise on hearing. Br. J. Indian Med. 1984, 41, 122-132. [CrossRef]

69. Barnes, M.E.; Hewitt, C.R.; Parker, T.M. Fish hatchery noise levels and noise reduction techniques. J. Agric. Saf. Health 2015, 21, 187-195. [PubMed]

70. Voorhees, J.; Barnes, M.E. Occupational noise levels in two rearing buildings at an aquaculture facility in South Dakota. Occup. Dis. Environ. Med. 2017, 5, 58-66. [CrossRef]

71. Moreau, D.; Neis, B. Occupational health and safety hazards in the Atlantic Canadian aquaculture: Laying the groundwork for prevention. Mar. Policy 2009, 33, 401-411. [CrossRef]

72. Mitchell, T. Aquaculture and ergonomics: Issues and opportunities. Ergon Aust. 2002, 16, 25-29.

73. Guertler, C.; Speck, G.M.; Schmidt, G.M.G.; Merino, A.D.; Merino, E.A.D.; Seiffert, W.Q. Occupational health and safety management in oyster culture. Aquac. Eng. 2016, 70, 63-72. [CrossRef] 